\title{
Prejudicial Publicity in Trials of Public Officials
}

One of the most intractable problems of the criminal justice system has been the effect of the freedom of the press on criminal defendants' right to a fair trial. Until recently, courts and commentators addressing the problem have focused on the available procedures for mitigating the effects of prejudicial publicity. By now it is well-settled that various procedural safeguards are required when there is a reasonable likelihood of prejudice to the defendant. ${ }^{1}$ But it is also recognized that residual préjudice may still linger after the use of any or all of the established methods-change of venue ${ }^{2}$ or venire, ${ }^{3}$ continuance, ${ }^{4}$

1. Sheppard v. Maxwell, 384 U.S. 333, 362-63 (1966); Rideau v. Louisiana, 373 U.S. 723, 726 (1963). Prejudice may be presumed from massive publicity; actual prejudice need not be shown. In Rideau, the Supreme Court, "without pausing to examine a particularized transcript of the voir dire examination," reversed the defendant's conviction because of the publicity surrounding his trial. Id. at 727.

2. Change of venue leaves open the obvious possibility that publicity will also be engendered in the area to which the trial has been transferred. See Irvin v. Dowd, 366 U.S. 717 (1961). Also, change of venue is useless if the publicity has been nationwide, or, in a court of limited jurisdiction, if the publicity has been spread through the entire jurisdiction. Application of Roy M. Cohn, 332 F.2d 976, 977 (2d Cir. 1964); Geagan v. Gavin, 292 F.2d 244, 246 (1st Cir. 1961), cert. denied, 370 U.S. 903 (1962). See also Estes v. Texas, 381 U.S. 532 (1965). For further discussion of the efficacy of change of venue in mitigating prejudicial publicity, see Austin, Prejudice and Change of I'ente, 68 Dick. L. REv. 401 (1964); Stanga, Judicial Protection of the Criminal Defendant Against Adverse Press Coverage, 13 WM. \& MARY L. Rev. 1, 11-22 (1971); Note, The Right to an Impartial Jury, 60 ColuM. L. REv. 349, 360-65 (1960); Note, The Efficacy of a Change of Venue in Protecting a Defendant's Right to an Impartial Jury, 42 Notre Dame L.1w. 925 (1967).

3. Change of venire-the summoning of jurors from another locale-shares the basic defects of change of venue. It is useless where the publicity has been disseminated throughout the jurisdiction from which the court can summon a jury. H. Felsher \& M. Rosen, The Press in the Jury Box 200-01 (1966); Note, The Right to an Impartial Jury, supra note 2, at $365 \cdot 67$.

4. Continuance offers no assurance that the effect of prejudicial publicity will lessen during the period of the continuance or that publicity will not be revived as the new trial date draws near. There is also a danger to both the prosecution and defense that important witnesses and evidence may not be available at a later date. Additionally, a continuance may conflict with a defendant's Sixth Amendment right to a speedy trial. H. Felsher \& M. Rosen, supra note 3, at 201-02; A. Friendly \& R. Goldfarb, Crime AND Publicity 96-101 (1967); Stanga, supra note 2, at 11-22; Note, The Right to an Impartial Jury, supra note 2, at 367-70; Comment, The Impartial Jury-Twentieth Century Dilemma: Some Solutions to the Conflict Between Free Press and Fair Trial, 51 Cornell L.Q. 306, 314-15 (1966). 


\section{voir dire, ${ }^{\overline{5}}$ severance, ${ }^{6}$ waiver of jury trial, ${ }^{7}$ sequestration, ${ }^{s}$ and ju- dicial instructions. ${ }^{9}$ Even silence orders directed to the participants ${ }^{10}$}

5. The very act of asking a juror whether he has seen or heard a prejudicial newspaper report or radio broadcast can call attention to the prejudicial publicity that the defendant hopes to mitigate. Irvin v. Dowd, 366 U.S. 717, 728 (1961); Maryland v. Baltimore Radio Show, 338 U.S. 912, 916 (1950) (Frankfurter, J., concurring in the denial of a petition for certiorari). Also, if the alleged crime has received extensive publicity, a voir dire which eliminates those jurors who have been exposed to the publicity may, as the Supreme Court has acknowledged, leave the defendant with jurors who are generally uninformed and not capable of satisfactory service on a jury. Irvin v. Dowd, supra at 722; Reynolds v. United States, 98 U.S. 145, 155-56 (1878). Furthermore, it is quite possible that prejudiced jurors would be unwilling to admit their prejudice or would even be unconscious of it, while well-intentioned but naive jurors would admit their slightest predisposition and thus be challenged. A. FriendLy \& R. GoldFarb, supra note 4, at 103. For a general discussion of voir dire, see Broeder, T'oir Dive Examinations: An Empirical Study, 38 S. CAL. L. Rev. 503 (1965).

6. Of course, severance is a theoretical possibility only in multidefendant trials. Among a group of co-defendants, although severance may be useful to those who have received relatively less publicity than other co-defendants, severance clearly provides no assistance to those other defendants who have been the primary focus of the publicity. H. FELSHER \& M. Rosen, supra note 3, at 202.

7. It has been suggested that judges are less swayed by extraneous issues than jurors. H. Kalven \& H. Zeisel, The American JuRY 495 (1966). There are, however, constraints on the defendant's ability to waive a jury trial. FED. R. Crim. P. 23(a) provides, "Cases required to be tried by jury shall be so tried unless the defendant waives a jury trial in writing with the approval of the court and the consent of the government." (Emphasis added.) The constitutionality of this rule was upheld in Singer v. United States, 380 U.S. 24 (1965). State practice varies, but in some jurisdictions the defendant's right to waive a jury trial is subject to limitations. E.g., State v. Fraser, 298 N.E.2d 423 (Ind. 1973); State v. Burnett, 194 Kan. 126, 397 P.2d 346 (1964); State v. Taylor, 391 S.W.2d 835 (Mo. 1965); State v. Scalise, 131 Mont. 238, 309 P.2d 1010 (1957).

On waiver of jury trials generally, see Donnelly, The Defendant's Right to Waive Jury Trial in Criminal Cases, 9 U. FLA. L. Rev. 247 (1956); Orfield, Trial by Jury in Federal Criminal Procedure, 1962 Duke L.J. 29; Note, Waiving the Right to a Jury Trial in the Federal Courts: The Burden of Prejudice, 7 Suffolk U.L. REv. 973 (1973).

8. When effectively applied, sequestration can prevent further publicity from reaching the jurors after they have been impaneled. It clearly does not remove the effects of prior publicity. Moreover, the sequestered jurors may feel resentment toward the party who they know, or believe, requested sequestration. Meyer, Free Press v. Fair Trial: The Judge's View, 41 N.D.L. REv. 14, 17-18 (1964); Will, Free Press v. Fair Trial, 12 DEP.uv L. Rev. 197, 209 n.39 (1963). See generally Comment, Sequestration: A Possible Solution to the Free Press-Fair Trial Dilemma, 23 AM. U.L. Rev. 923 (1974).

9. Judicial instructions are widely criticized as being ineffective and, at times, harmful because they call the jury's attention to the publicity in question. See, e.g., Krulewitch v. United States, 336 U.S. 440, 453 (1949) (Jackson, J., concurring); Notc, The Case Against Trial by Newspaper: Analysis and Proposal, 57 Nw. U.L. REv. 217, 229 n.2(1) (1960).

10. See Comment, Gagging the Pross in Criminal Trials, 10 Hurv. Civ. RigusCiv. Lib. L. Rev, 608, 618-22 (1975); ABA, Project on Minimum Standards for Crimin.iI. Justice, Standardos Relating to Fair Trial and Free Press 98-111 (Tent. Draft, 1966); Special Comir. on Radio, Television, and the Administration of Justice of the Ass'N of the Bar of the City of New York, Freedom of the Press and Fitr Trial. $38-47$ (1967). Placing restrictions on dissemination of news through the police, lawyers, and the availability of police records raises the likely possibility that the media would turn to other and less reliable sources. Foreman, $A$ Free Press and a Fair Trial-A Defense Attorney's Viez', 11 VILL. L. Rev. 704, 707 (1967). More importantly, nothing would stop the media from publishing the allegedly prejudicial information once it had been obtained. 
in trials or to the press itself ${ }^{11}-$ whatever the permissible scope of these orders under the First Amendment ${ }^{12}$ - cannot guarantee a trial free from prejudice. If a reasonable likelihood of prejudice exists after all the applicable procedural requirements have been met, a fundamental question arises: does this residual prejudice deny the defendant a fair trial? This Note contends that it does not, at least in trials of public officials for crimes related to their office.

The leading Supreme Court cases on prejudicial publicity have concerned trials in which the judge failed to apply particular procedures for mitigating the effects of publicity. The problem before the Court has been whether this failure resulted in a substantial possibility of prejudice, and the solution has been to reverse and remand the case for a new trial.

11. Silence orders issued to the media-enforced by the threat of a contempt citationare of doubtful constitutionality. Judicial Conference of the U.S., Comm. on the Operation of the Jury System, Report on the "Free Press-Fair Trial" Issue, 45 F.R.D. 39I, 401.02 (1968) (adopted by the Judicial Conference, ANNuAL RerorT OF THE Director of the Administritive Office of the United States Courts 1968, at 66-67); AB.A. Project on Minimua Standards for Criminal Justice, Standards Relitixc to fair Trial and Free Press 27 (Proposed Final Draft, 1967); Srecint Comm., supra note 10, at 11 . Cases decided since the publication of the above reports cast further doubt on the constitutionality of government control or restraint of the media. Cox Broadcasting Corp. v.. Cohn, 420 U.S. $469,493-95$ (1975) (sanctions on the publication of truthful information contained in official court records open to public inspection held unconstitutional); Miami Herald Publishing Co. v. Tornillo, 418 U.S. 241, 254-58 (1974) (candidates' right of reply statute held unconstitutional); Organization for a Better Austin v. Keefe, 402 U.S. $415,418.20$ (1971) (injunction forbidding the distribution of informational pamphlets did not meet the "heavy burden of showing justification" for the imposition of a prior restraint); Times-Picayune Publishing Corp. v. Schulingkamp, 419 U.S. 1301 (1974) (Powell, J., Circuit Justice) (granting stay of order restricting media coverage of criminal trial), dismissed as moot, 420 U.S. 985 (1975). But see Branzburg v. Hayes, 408 U.S. 665, 684-85 (1972) ("Newsmen ... may be prohibited from attending or publishing information about trials if such restrictions are necessary to assure a defendant a fair trial before an impartial tribunal.") (dictum). For a recent discussion of the constitutionality of silence orders, see Comment, supra note 10.

Even if the constitutional objections-as well as the political objections-could be overcome, silence orders are still an incomplete solution to the problem of prejudicial publicity. As has been said of the use of the contempt power in England to prevent such publicity:

The greatest failure of English contempt law is its distelation with its most valuable object-protection of fair trials. It is of little service to an accused person who is written into jail by a prejudiced press that the publisher or editor is fined or imprisoned.

R. Goldfarb, The Contempr Power 88 (1963).

12. This Note does not attempt to determine the constitutional limits on the use of silence orders. Rather it assumes that, at least as long as those limits do not shift radically, silence orders cannot eliminate the effects of prejudicial publicity. The Note addresses problems arising after courts have done everything reasonably within their power to mitigate the effects of publicity. The determination of what is properly within a court's power is, of course, more difficult in the case of silence orders than other procedures for mitigating publicity, especially under "balancing" theories of the First Amendment. See sources cited in note 11 supra. 
The landmark case on prejudicial publicity is Sheppard $\%$. Maxwell. ${ }^{13}$ The Court held that Sheppard, who had been convicted of murder in a state court, was entitled to habeas corpus on the ground that massive prejudicial publicity had deprived him of his constitutional right to a fair trial. The court dwelt at length on the errors of the trial judge and on the remedial measures the judge might have used. Considering the "deluge of publicity"14 that surrounded the trial, the Court found reversible error in the trial court's failure to use means to "reduce the appearance of prejudicial material and to protect the jury from outside influence" 15 -the failure, for example, to limit the presence of the press, to attempt to stop "the release of leads, information, and gossip,"10 to grant a continuance or change of venue, and to sequester the jury. ${ }^{17}$ The Court concluded that "these procedures would have been sufficient to guarantee Sheppard a fair trial . ..."1s

The Supreme Court had earlier relied on a similar analysis in Rideau v. Louisiana ${ }^{19}$ to reverse the petitioner's state court conviction. Rideau had been arrested soon after a man had robbed a bank, kidnapped three of the bank's employees, and killed one of them. The next morning, and on the two succeeding days, a filmed "interview" between Rideau and the local sheriff was shown on television in which Rideau admitted that he had committed the bank robbery, kidnapping, and murder. After his arraignment two weeks later, Rideau filed a motion for change of venue. This was denied and he was convicted in the trial court of the parish. The Supreme Court reversed the conviction, holding "that due process of law in this case required a trial before a jury drawn from a community of people who had not seen and heard Rideau's televised 'interview." "20 Although based on

13. 384 U.S. 333 (1965).

14. Id. at 357 .

15. Id. at 358 .

16. Id. at 359 .

17. $I d$. at 363 .

18. Id. at 358 . On retrial, Sheppard was acquitted. N.Y. Times, Nov. 17, 1966, at 1, col. 7.

19. 373 U.S. 723 (1963).

20. Id. at 727. On the ground of denial of a fair trial in violation of the due process clause, the Supreme Court also reversed a state court conviction in Estes v. Texas, 381 U.S. 532 (1965) (in which a hearing preceding the defendant's trial and portions of the trial itself were televised). On the same ground, the Court vacated and remanded Irvin v. Dowd, 366 U.S. 717 (1961) (in which the defendant's first motion for change of venue was granted but a second motion was denied and in which eight of the 12 jurors admitted on voir dire that they thought the defendant was guilty).

In its most recent decision on prejudicial publicity and the right to a fair trial, however, the Supreme Court held that the jurors' exposure to publicity concerning the defendant's past crimes, his flamboyant life style, and the alleged crime for which he was being tried did not deprive the defendant of a fair trial, since voir dire indicated no preconceptions on the jurors' part. Murphy v. Florida, 95 S. Ct. 2031 (1975). 
the trial court's failure to order a change of venue, the Supreme Court's holding in Rideau also suggested that if no community could be found which had not been powerfully influenced to believe the defendant's guilt, a fair trial could not be held at all.21

The possibility foreseen by the Court resurfaced, in particularly dramatic form, in the recent case of Calley $v$. Calloway. ${ }^{22}$ Calley, a second lieutenant in the United States Army, had been convicted by court-martial of premeditated murder and assault with intent to commit murder at My Lai during the Vietnam War. He sought habeas corpus in the federal courts on the ground, among others, that he "was denied a fair and impartial trial because of massive adverse pretrial publicity." tional publicity accompanying Calley's prosecution had engendered a level of prejudice which, regardless of the procedural protections used, would render a conviction invalid. It stated that "[n]ever in the history of the military justice system, and perhaps in the history of American courts, has any accused ever encountered such intense and continuous prejudicial publicity as did the Petitioner herein." ${ }^{24}$ According to the court, "this publicity was so inherently prejudicial as to require reversal," ${ }^{25}$ and it stressed the intrinsic weaknesses of change of venue,

21. This suggestion was noted by the Fourth Circuit in United States v. Abbott Laboratories, 505 F.2d 565 (4th Cir. 1974), cert. denied, 420 U.S. 990 (1975). A drug company and its officers had been indicted on several counts charging them with misdemeanors involving the introduction into interstate commerce of allegedly adulterated and misbranded drugs. Extensive pretrial publicity had included stories imputing, variously, nine deaths or $\mathbf{5 0}$ deaths to the defendants' products. The district court found that change of venue, continuance, and voir dire would not sufficiently overcome the effects of massive pretrial publicity to ensure a fair trial and, accordingly, dismissed the indictments. 369 F. Supp. 1396 (E.D.N.C. 1973). Government agencies and departments were found to be the sources of some of these stories-a factor that weighed heavily with the district court. Id. at 1403. The Fourth Circuit declined to adopt the district court's standard as to what was impermissibly prejudicial publicity and reversed the district court's decision. It held that the pretrial publicity had not been so inflammatory that a fair trial was absolutely precluded, and that it was improper to dismiss the indictment without at least an attempt to see if an impartial jury could be provided. The court acknowledged, however, that Rideau $v$. Loutisiana does "suggest that pretrial publicity may be so prejudicial that no trial by jury drawn from the community in which it was disseminated would be constitutionally fair, and thus that the prosecution should be quashed if a change of venuc to an unpolluted community is not possible." 505 F.2d at 571 . The court did not deny that Abbott might be such a case; it merely held that such a determination should not be made before the lower court had even attempted to impanel a jury. Id. at 571 .

22. 382 F. Supp. 650 (M.D. Ga. 1974), rev'd, 17 Crim. L. Rer. 2500 (5th Cir., Sept. 9 $1975)$.

23. 382 F. Supp. at 656.

24. Id. at 657 .

25. Id. Later in its opinion the court noted, "The record in this case shows'that the Petitioner's trial was affected by isolatable demonstrated prejudice and by inherent - prejudice to such an extent that the petitioner was denied due process. Judged by cvery standard established by the decided cases, his conviction should be set aside. 
continuance, and voir dire. ${ }^{20}$

On appeal the Fifth Circuit, sitting en banc, reversed the district court chiefly because, in its view, the intense publicity had not been prejudicial to Calley. ${ }^{2 \pi}$ In addition, the Fifth Circuit suggested that it was satisfied with the procedures used by the trial court in the circumstances, emphasizing that the court-martial had been preceded by a careful voir dire, ${ }^{28}$ and that "the military court did the best it could to control publicity."29

The difference between the district court and the Fifth Circuit concerning the actual harm to Calley from the publicity surrounding his case conceals a fundamental problem that courts may no longer be able to avoid. It is now possible that the elaboration of procedural safeguards designed to offset the effects of prejudicial publicity has matured to a point where for the first time the problem of publicity faces the courts in its most elemental form: assuming that all practicable safeguards have been used, what amount, if any, of possible residual prejudice in the juirors' minds justifies setting aside a conviction?

Recent and impending prosecutions attended by publicity as massive and protracted as any in history may force a resolution of this question by the Supreme Court. The prosecutions of the Watergate defendants ${ }^{30}$ followed two years of charges, headlines, nationally televised hearings, impeachment proceedings, and finally the resignation and subsequent pardon of a close associate of the defendants, the President of the United States. It may have been literally impossible to empanel a jury anywhere in the nation that did not have some preconception of the guilt or innocence of the defendants. Similarly the conduct and motives of Patricia Hearst, who may be tried in the

Stated otherwise, if there has ever been a case in which a conviction should be set aside because of prejudicial publicity, this is it." Id. at 691 (emphasis in original).

26. Id. at 687 . A similar approach has been adopted in other highly publicized cases. In the Eastern District of Wisconsin, Judge Gordon dismissed federal indictments against 10 defendants accused of destroying Selective Service records. He observed that, of the 142 prospective jurors, only one had not heard of the case. N.Y. Times, June 12, 1969, at 9 , col. 1 . In the murder trial of Black Panther leader Bobby Seale and others, the jury was unable to reach a rerdict and Judge Mulvey then granted a defense motion to dismiss all the charges against the defendants. Despite the considerable efforts that had been made to ensure a fair trial, Judge Mulvey stated, "I find it impossible to bclievc that an unbiased jury could be selected without superhuman effort-efforts which this court, the state and these defendants should not be called upon either to make or to endure." N.Y. Times, May 26,1971 , at 1 , col. 5 .

27. 17 Crinr. L. Rep. 2500 (5th Cir., Sept. 9, 1975).

28. Id. at 2501 .

29. Id.

30. Ehrlichman v. Sirica, 419 U.S. 1310 (1974) (Burger, C.J., Circuit Justice); United States v. Mitchell, Crim. No. 74-110 (D.D.C., Jan. 1, 1975), notice of appeal filed, No. 75-1381 (D.C. Cir., Feb. 28, 1975). 
foreseeable future, were a matter of daily speculation throughout the country for more than a year.

The problem posed by these prosecutions was adumbrated in the Calley case. The district court, anticipating that its decision might be read as removing an entire class of defendants from the reach of criminal justice, asserted that " $[t]$ his opinion of the Court should not be construed as holding that if an individual who is charged with offenses achieves sufficient notoriety as a result of his alleged acts the charges should be dismissed." 31 Notwithstanding this disclaimer, it is hard not to construe the district court's opinion as meaning that a defendant so adversely affected by publicity as Calley could never be convicted.

A theory of fairness which requires more than the timely application of established procedural protections-and asks that convictions not be upheld where possible residual publicity exceeds a specific level -will have the effect of preventing altogether the trial of certain defendants for certain notorious crimes. ${ }^{32}$ This result, while not appealing in any case, is particularly unsettling when applied to high public officials, on whom the successful operation of our political institutions largely depends. Nevertheless, if this standard of fairness were constitutionally required in trials of public officials, the courts would of course have to adopt it. The Constitution does not, however, go that far.

The Constitution guarantees due process of law to criminal defendants in all courts, and spells out a specific requirement of an "impartial jury" in federal prosecutions. ${ }^{33}$ Due process is a function both

31. 382 F. Supp. at 691 .

32. A recent Comment adopts such a theory and reluctantly accepts its consequences. Comment, supra note 10. Citing Rideau v. Louisiana, 373 U.S. 726 (1963), the Comment states that "a conviction cannot stand if it results from the state's failure to provide a trial free from prejudice," Comment, supra at $61 \mathrm{l}$, and proposes as the constitutional standard that "jurors not be exposed to influences which would interfere with the openminded and fair determination of guilt or innocence." Id. at 616. Applying this standard, it admits the likelihood that, given the First Amendment test it proposes for the issuance of gag orders, "some convictions [in the Watergate cases] will be reversed as a result [of prejudicial publicity]." Id. at 635 .

33. U.S. Consr. amend. VI provides:

In all criminal prosecutions, the accused shall enjoy the right to a speedy and public trial, by an impartial jury of the State and district wherein the crime shall have been committed, which district shall have been previously ascertained by law, and to be informed of the nature and cause of the accusation; to be confronted with the witnesses against him; to have compulsory process for obtaining witnesses in his favor, and to have the Assistance of Counsel for his defence.

The "impartial jury" provision in the Sixth Amendment has not yet been held applicable to the states through the Fourteenth Amendment, although other provisions of the Sixth Amendment have been. See Duncan v. Louisiana, 391 U.S. 145, 158 (1968).

In reviewing state court convictions allegedly tainted by publicity, the Supreme Court has based its decisions on the Fourteenth Amendment's due process clause which, the Court has held, entitles the defendant to a fair trial. E.g., Sheppard v. Maxwell, 384 
of history and of fundamental fairness. History has no immediate voice in the problem at hand because only recently has massive and protracted nationwide publicity become a common incident of criminal trials. The problem of media-induced bias which cannot be purged from jurors' minds has yet to be addressed squarely by the courts. As to fairness, the essential determination must rely on the circumstances of specific cases or classes of cases.

The Sixth Amendment requirement of an "impartial jury" is necessarily informed by the idea of fundamental fairness. While this idea immediately excludes jurors who have a stake in the outcome or are personal foes of the accused, a standard of absolute impartiality is, equally clearly, beyond reach. In Justice Minton's famous dictum, "[a] defendant is entitled to a fair trial but not a perfect one." 3 t

The essential circumstance governing the question of fairness in trials of public officials is that in our society such defendants are people who have chosen to put themselves and their conduct before the public. Exposure to extensive publicity has for years been an acknowledged fact of public life. It is a prerequisite of campaigning for office and a concomitant of holding it. Publicity cannot but follow upon allegations of misdeeds by public officials. Indeed, the press is widely believed to have an obligation to subject the conduct of public officials to close scrutiny. Even if society's decision to allow such a role to the press were ultimately misguided, it would still bear decisively on the question of fairness in trials of public officials. Unlike most other citizens, public officials can legitimately be said to have assumed the risk of publicity surrounding allegations of misconduct. In the circumstances, it can hardly be considered unfair to make them accountable for their actions in criminal trials (assuming appropriate procedural safeguards), even if the effects of publicity cannot be purged from the jurors' minds.

U.S. 333 (1966); Estes v. Texas, 381 U.S. 532 (1965); Rideau v. Louisiana, 373 U.S. 723 (1963); Irvin v. Dowd, 366 U.S. 717 (1961). It is somewhat unclear whether-as regards prejudicial publicity-any difference exists between the impartial jury rcquirement and the due process requirement. The Court has tended to equate the two. In Invin $v$. Dowd, for instance, the Court noted, "In essence, the right to jury trial guarantees to the criminally accused a fair trial by a panel of impartial, 'indifferent' jurors. 'The failure to accord an accused a fair hearing violates even the minimal standards of dtie process." $I d$. at 722. It is clear, however, that the Court is more willing to revcrse convictions-because of the effects of prejudicial publicity-under its "stupervisory power to formulate and apply proper standards for enforcement of the criminal law in the federal courts," Marshall v. United States, 360 U.S. 310, 313 (1959) (per cuxiam), than "as a matter of constitutional compulsion." Murphy v. Florida, 95 S. Ct. 2031, 2035 (1975).

34. Lutwak v. United States, 344 U.S. 604,619 (1953). The Lutwal dictum has often been cited by courts in denying appeals on grounds of prejudicial publicity. See, e.s., United States v. Hoffa, 367 F.2d 698, 709-10 (7th Cir. 1966); Pcople v. Robertsoin, it Ill. App. 2d 360, 363, 220 N.E.2d. 5, 7 (1966). 
There are analogous ideas of fairness expressed in other areas of constitutional law. The Supreme Court has recognized that certain common law rights of those who become public officials can properly be made to depend on their ability to have anticipated intense exposure to public scrutiny. In New York Times Co. $v$. Sullivan, ${ }^{35}$ the first in a line of decisions attempting to harmonize the law of defamation with the demands of the First Amendment, the Court concluded that a public official could not recover from a newspaper for false statements of fact made without actual malice. In Gertz $v$. Robert Welch, Inc., ${ }^{36}$ the most recent of the sequels to New York Times, the Court refused to extend the New York Times principle to statements about private individuals. Distinguishing public officials and public figures from private individuals, the Court in Gertz advanced the view that it is fair to treat public officials as having accepted the "necessary consequences" of "closer public scrutiny": ${ }^{37}$

An individual who decides to seek governmental office must accept certain necessary consequences of that involvement in public affairs. He runs the risk of closer public scrutiny than might otherwise be the case. And society's interest in the officers of government is not strictly limited to the formal discharge of official duties. .. . The public's interest extends to "anything which might touch on an official's fitness for office ...."

Even if the foregoing generalities do not obtain in every instance, the communications media are entitled to act on the assumption that public officials and public figures have voluntarily exposed themselves to increased risk of injury from defamatory falsehood concerning them.

The analogy of New York Times and Gertz with the problem of fair trials is admittedly not perfect. In the New York Times line of cases, various common law and statutory rights to recover in defamation were made to yield to freedoms guaranteed by the First Amendment. The problem here is to determine the boundaries of the constitutional rights of public officials accused of crimes.

35. 376 U.S. 254 (1964).

36. 418 U.S. 323 (1974).

37. Id. at 344.45 (citation omitted). The possibility of applying the Gertz rationale in this context was suggested but rejected in Comment, supra note 10 , at 635 n.141. The Comment observes that one way for courts to avoid reversals of the convictions of high political officials because of prejudicial publicity "would be to set a different prejudice standard." Id. This Note does not contend that the standard of fairness for private citizens should necessarily be different from that for public officials. It does contend, however, that a standard of fairness which requires only that all procedural protections be reasonably applied is most justified when the defendant is a public official. 
There are instances, however, in which the Supreme Court has recognized that the extent of one's constitutional rights can turn on one's status as a public official. The Court has consistently upheld $\$ 9$ of the Hatch Act, ${ }^{38}$ which prohibits political activity by public employees, against First and Fifth Amendment challenges. The Court's most recent pronouncement to this effect is in United States Civil Service Commission v. National Association of Letter Carriers, ${ }^{30}$ where the Court stated, "Our judgment is that neither the First Amendment nor any other provision of the Constitution invalidates a law barring this kind of partisan political conduct by federal employees." $\$ 0$ The Court concluded in Letter Carriers that the scope of public employees' rights of expression and political association could be determined in part by society's interest in "fair and effective government": ${ }^{41}$

Until now, the judgment of Congress, the Executive, and the country appears to have been that partisan political activities by federal employees must be limited if the Government is to operate effectively and fairly .....

... [T] he government has an interest in regulating the conduct and "the speech of its employees that differ[s] significantly from those it possesses in connection with regulation of the speech of the citizenry in general. The problem in any case is to arrive at a balance between the interests of the [employee], as a citizen, in commenting upon matters of public concern and the interest of the [government], as an employer, in promoting the efficiency of the public services it performs through its employees."

Society's interest in responsible government similarly supports the solution offered here to the problem of publicity in trials of public officials.42 Misconduct by public officials, which tends to affect the state itself, threatens the power of the people to govern through their representatives, and ultimately places the rule of law in jeopardy. The need to hold public officials accountable is correspondingly great. If the public interest can justifiably shape government employees' rights

38. 5 U.S.G. \& 7324 (Supp. III 1973). See United Public Workers v Mitchell, 330 U.S. 75 (1947); United States Civil Serv. Comm'n v. National Ass'n of Letter Carriers, 413 U.S. 548 (1973).

39. 413 U.S. $548(1973)$.

40. Id. at 556 .

41. Id. at 564 (citation omitted).

42. Of course, it could be argued that the investigative resources of Congress and the media provide more appropriate means of protecting the public interest in preventing officials' misconduct than do criminal trials. Neither Congress nor the media, however, are required to provide judicial safeguards in such investigations, nor are they really capable of assuming the role of the courts in establishing guilt. Further, the publicity generated by congressional or journalistic investigations can compound the threat to an impartial trial. See, e.g., Delaney v. United States, 199 F.2d 107, 111 (Ist Cir. 1952). 


\section{Prejudicial Publicity in Trials of Public Officials}

of speech and association, it would seem no less to justify subjecting public officials to some of the inevitable consequences of public scrutiny. ${ }^{43}$

There remains the difficult question of who should be considered a public official. Some state laws provide definitions of public officials for administrative purposes, but the Supreme Court has refused to accept these definitions as relevant for purposes of the New York Times principle, which involves a "national constitutional protection." 44 The Court's efforts to delineate those included within the New York Times principle provide a useful analogy in defining a public official for purposes of the fairness standard proposed here.

Although the Court in New York Times announced a case-by-case approach for deciding who is a public official, ${ }^{45}$ in Rosenblatt $v$. Baer

43. Other examples of limitations imposed on public officials and employees are also revealing. Although perhaps not as dramatic as the New York Times principle or the Hatch Act, these limitations concern important interests. For instance, various state and local laws curtail (at least in theory) public employees' right to strike. See W'itt, The Public Sector Strike: Dilemma of the Seventies, 8 CAL. W.L. REv. 102 (1971). In recent years, federal as well as state legislation has been enacted to compel financial disclosure by candidates for and holders of particular offices. See, e.g., Note, The Constitutionality of Financial Disclosure Laws, 59 CoRnell L. Rev. 345 (1974); Note, Public Officials: The Constitutional Implications of Mandatory Public Financial Disclosure Statutes, and a Proposal for Change, 1971 LAw \& Soc. ORd. 104; Note, Mandatory Financial Disclosure Statements From Public Officials-Unwarranted Intrusion or Legitimate Public Concern?, 45 TuL. L. REv. 167 (1970). The common law has for centuries forbidden public officials from holding what it considered to be incompatible offices. Knuckles v. Board of Educ., $272 \mathrm{Ky.} \mathrm{431,} 114$ S.W.2d 511 (1938); Howard v. Harrington, 11.4 Me. 443, 96 A. 769 (1916); Weza v. Auditor Gen., 297 Mich. 686, 298 N.W. 368 (1911); Note, The Common Law Rule Against Holding Incompatible Offices-Abolishing the "Office" Limitation, 9 LAND \& Water L. Rev. 667 (1974). Also, prior to and sometimes during employment, some government employees must take loyalty oaths or undergo security investigations. Developments in the Late-The National Security Interests and Civil Liberties, 85 HaRv. L. REv. $1130,1160-89$ (1972).

Of course, not every instance of the law's special treatment of public officials is to their detriment. The law confers on some public officials, in some circumstances, legal protections not accorded other citizens. There is, for example, the well-established principle of state and federal common law that public officials and public employees are not liable for unintentional fault in the exercise of discretionary functions. $3 \mathrm{~K}$. DAvis, ADMinistrative LAw TREstise $\$ 26.01$, at 506 (1958). Similarly, the Supreme Court has held that an absolute privilege protects the utterances of federal officials if made "within the outer perimeter" of their duties. Barr v. Matteo, 360 U.S. 564, 575 (1959).

Thus, public officials can be subject both to particular legal disabilities and particular legal protections; the law has been willing, in a number of different situations, to recognize that there are special considerations governing the legal status of public officials, and to shape legal doctrines accordingly. The standard proposed in this Note can be seen as such a doctrine, fully warranted by the special status of public officials when they are defendants in criminal prosecutions.

41. Rosenblatt v. Bacr, 383 U.S. 75, 84 (1966) (footnote omitted).

45. New York Times Co. v. Sullivan, 376 U.S. 254, 283 n.23 (1964). The Court has also adopted this case-by-case approach in deciding to whom besides public officials the Ncw York Times principle should apply. See Gertz v. Robert Welch, Inc., 418 U.S. 323 (1974); Rosenbloom v. Metromedia, Inc., 403 U.S. 29 (1971); Curtis Publishing Co. v. Butts, 388 U.S. 130 (1967). 
it set forth a core definition: ${ }^{46}$

It is clear, therefore, that the "public official" designation applies at the very least to those among the hierarchy of government employees who have, or appear to the public to have, substantial responsibility for or control over the conduct of governmental affairs.

Courts have given this definition a broad interpretation. Rosenblatt was remanded for a determination whether a county recreation supervisor met the standard, which has subsequently been applied to appointive as well as elective positions. ${ }^{47}$

The Rosenblatt definition is a workable and logically defensible one for purposes of this Note. The idea of a knowing assumption of the burdens as well as benefits of public office is fairer and more realistic in the case of officials in the higher ranks of the government. Employees among the generally unheralded ranks of postal workers, for example, would, upon accepting employment, give scant thought to the possibility of publicity resulting from their status. A high official of local, state, or national government may, and definitely should, give considerable thought to the possible consequences of public scrutiny. It is also likely that public officials within the core definition have the greatest power to injure the public interest, a power which argues strongly for their accountability to the public.

The core definition of public official should, however, be applied more narrowly in trials surrounded by prejudicial publicity than in defamation actions. The latter involve the determination of the constitutional right of a defendant under the First Amendment; the former, of a criminal defendant under the Sixth Amendment. In either case close questions about the category of public official should be resolved in favor of those constitutional rights. Hence the status of "public official," which is broadly construed for plaintiffs in defamation, should be narrowly construed for criminal defendants.

There is the further question whether the proposed fairness standard should extend beyond trials for offenses related to office. Fairness does not clearly compel a distinction between officials' public and private conduct; one who assumes the burden of public scrutiny can hardly expect that scrutiny to stop at the statehouse. But the public interest in preserving the integrity of government does allow a dis-

46. Rosenblatt v. Baer, 383 U.S. 75, 85 (1966) (footnote omitted).

47. 383 U.S. at 87-88. See Time, Inc. v. Pape, 401 U.S. 279, 284 (1969) (Chicago deputy chief of police held a public official); Local 1581, AFT v. Ysrael, 492 F.2d 438 (9th Cir.), cert. denied, 419 U.S. 872 (1974) (officers of teachers' union). 
tinction. The rule of law is less immediately threatened by the private misconduct of public officials than by their breaches of duty. At the very least, then, the solution to the problem of publicity advanced here for trials of public officials-while conceivably applicable to all misconduct-is more strongly supported by public policy when applied to misconduct in office.

More broadly, the Constitution may require only that courts do all they reasonably can to mitigate the effects of prejudicial publicity in any trial. To reverse convictions because of prejudice which remains after the application of the available procedural safeguards would effectively immunize some defendants in highly sensational cases. It is open to question whether the guarantee of a fair trial compels this result for any defendant-public official or private citizen. 